\title{
STUDIES ON PLANKTON, PRIMARY PRODUCTION AND \\ FISH IN THE INNER BRUNEI BAY
}

by

\author{
OLOF LINDEN ${ }^{1}$, BJORN GANNING ${ }^{2}$ and LENNART LINDESTROM ${ }^{3}$
}

\section{INTRODUCTION}

The Brunei Bay is a relatively shallow enclosed water area (Figure 1), approx. $45 \times 45 \mathrm{~km}$ in size. Depth figures normally range between 30 and 40 meters. The bay is influenced by a number of rivers which discharge into the area, the largest being Padas in the north and Limbang in the south. The annual mean flow of Padas is estimated at $200 \mathrm{~m}^{3}$ per sec and the maximum over 1550 . The rivers contribute with large quantities of sediment into the bay, and this sediment is covering the seabed and cause turbidity of the water. The total amounts of suspended solids brought to Brunei Bay from the river Padas has been measured at 2000-3000 tos per day or about 1 million ton per year. The vegetation in the area north, east and south of Brunei Bay consists'of primary and secondary rain forest, rubber plantations and other crop, and mangrove swamps. In 1982-1983 large areas of tropical forest on Borneo was affected by fire. It has been estimated that, in East Kalimantan only, some 3,5 million hectares of forest were destroyed. The fires also affected close to 1 million hectares of tropical vegetation in western Sabah (MALINGREAU et al 1985) and it seems probable that there have been indirect effects also in the marine environment due to thess fires.

An area in the eastern central portion, the Gunong Lumako Forest Reserve, is since the last 5 years subject to extensive forestry operations involving systematic clear-cutting and plantation. This area is also being industrialized, involving for example the construction of a wood-, pulp- and papermill complex, the construction of an ocean harbor and various other infrastructures. The study reported here was carried out in 1984 and 1985 to provide some basic information on the marine ecosystems of the inner Brunei Bay. The present results cover studies of the diversity and abundance of the plankton, primary production, and fish fauna of the inner Brunei Bay. A separate report covers the state of the coral reefs in the area (LINDEN et al, 1988), and another report various physico-chemical parameters of the water and sediment (in preparation). The only plankton study available from Brunei Bay is the result of a preliminary study of the species composition of zooplankton carried out by MOHAMED et al (1984). Also with regard to the South China Sea in general, few studies have been reported. However, some baseline work has been carried out in the Straits of Malacca and along the east coast of Peninsular Malaysia (CHUA \& CHONG 1973, CHU A1984).

1) Swedish Environmental Research Institute (IVL) Box 21060, 10031 Stockholm, Sweden

2) Department of Zoology University of Stockholm, 10691 Stockholm, Sweden

3) Swedish Environmental Research Group Fryksta, 66500 Kil, Sweden 


\section{O. LINDEN; B. GANN1NG \& L LINDSTROM}

In the present study qualitative and semi-quantitative samples of phyto- and zooplankton were collected in Brunei Bay during November-December 1984 and April 1985. In addition, the amount of chlorophyll a was determined and the primary productivity was studied using the ${ }^{14} \mathrm{C}$ technique.

No previous results of scientific investigations of the fish fauna of Brunei Bay are available. However, a checklist of marine fishes of West Sabah, based on collection made in March 1974, have been published by CHUA\& CHAW (1978). In order to study the fish fauna of the area in Brunei Bay a number of fishing efforts using survey nets and a beach seine net were conducted in November-December 1984.

\section{METHODS}

Phytoplankton were sampled using a standard phytoplankton net (mesh size : $50 \mathrm{um}$, diameter : $15 \mathrm{~cm}$ ). One vertical haul from the sea bed to the surface was taken at each station. The samples were preserved in neutralized $4 \%$ formaldehyde solution. Qualitative and semi-quantitative analysis were carried out using an inverted microscope.

For the determination of chlorophyll a samples of $500 \mathrm{ml}$ of sea water collected at the surface and in the deep water were filtered through $0.45 u$ fibreglass filters in the field. The filters were stored in a freezer until they were analyzed for chlorophyll a according to standard methods.

Primary production was measured using ${ }^{14} \mathrm{C}$-technique according to standard methods. Water samples were incubated in glass flasks for 3 to 5 hours at 5 different depths (usually $0.5,5,8,12 \mathrm{~m}$ and $0.5 \mathrm{~m}$ above the bottom). Dark bottles were incubated at $0.5 \mathrm{~m}$ and at the largest depth. Four $u \mathrm{Ci}$ of carrier free $\mathrm{NaH}^{14} \mathrm{CO}_{3}$ were added to all bottles. After incubation the samples were acidified and the samples were aerated for 20 minutes. Ten $\mathrm{ml}$ of the samples were transferred to scintillation vi\&ls and counted in instagel (Packard Instruments) in an Intertechnique SL 40 liquid scintillation counter. The uptake of carbon was calculated according toGARGAS(1975).

Samples of zooplantkon were obtained by vertical net hauls from bottom to surface, using a Unesco WP-2 net with $90 u$ m mesh size. The samples were preserved in $4 \%$ formaldehyde solution. Counting and determination of groups were performed using an inverted microscope.

For fish sampling standard survey nets of $36 \mathrm{~m}$ length, $1.5 \mathrm{~m}$ height, divided into 12 sections, each with a length of $3 \mathrm{~m}$ with mesh size varying from $\%$ to 3 inches were used. Ten nets were utilized each time. Fishing was carried out in the day during $2 \frac{1}{2}$ to 5 hours, or through the night during 13 hours. The stations are shown in Figure 2.

For nearshore fishing a beach seine net measuring $28.8 \mathrm{~m}$ in length and $1.5 \mathrm{~m}$ in height with a mesh size of $6 \mathrm{~mm}$ was used. At each station 4 to 7 shootings of the net were conducted, each covering an area of approx. $2.500 \mathrm{~m}^{2}$. At each occasion the shootings were carried out around noon and the stations are shown in Figure 2. 
Studies on Plankton

\section{RESULTS AND DISCUSSION}

\section{Phytoplankton}

At least 78 species of phytoplankton were recorded during the two sampling periods. The results are shown in Table 1. In November-December some 71 species were obtained, while in April some 48 species were recorded. Also with regard to abundance, higher figures were noted in November-December compared to April. The dominating genera in November-Desember were diatoms such as Bacteriastrum, Chaetoceros and Rhizosolenia These are large organisms which occurred in high abundance. In April these genera were also noted but, with few exceptions, much less abundant than five months earlier. Instead blue-green algae (Oscillatoria) dominated all samples collected in April. This group was only found occasionally during November-December.

Hence, larger species diversity and abundance were recorded in NovemberDecember compared to April. The situation in April could indicate that lower concentrations of nutrients were available, resulting in lower phytoplankton activity. These observations were confirmed in the studies of chlorophyll and primary production (see below).

The results of the chlorophyll a analysis, shown in Table 2, indicate two to three times higher figures during November-December compared to April. These results are in agreement with the results of the studies of the species diversity and abundance reported above.

The primary production measured as $\mathrm{C}^{14}$-uptake was 3 times higher in NovemberDecember compared to April (Table 3). If a $12 \mathrm{hr}$ daylight period is assumed, the autumn value is on average slightly over $550 \mathrm{mg} \mathrm{C} \mathrm{m}$ day, and the spring value slightly over $150 \mathrm{mg}$ C. Assuming that the year is divided into autumn and spring production, the integrated production on the whole year may be calculated as $100-150$ $\mathrm{g} \mathrm{C} \sim^{2}$. Such figures are in general in accordance with what would be expected from coastal tropical areas. RYTHER (1969) reports values in that range. However, the difference in primary production between autumn and spring, may seem remarkable for a tropical area. This difference is possibly at least partly determined by the loss of nutrients and differences in turbidity due to land run-off. The annual precipitation in the area approaches 4000 millimeter/year, and the most pronounced rainy period is October to January.

\section{Zooplankton}

The results of the studies of the zooplankton population are shown in Tables 4 and 5. Generally the most common group is crustaceans with copepods frequently being abundant. Shrimp larvae were recorded in most samples. Tunicates and chaetognates appeared to be slightly more common in April compared to NovemberDecember. Otherwise no obvious differences could be observed between the two sampling periods. 


\section{O. LINDEN; R GANNING \& L LINDSTROM}

Fish

The results of the fishing using survey nets are shown in Tables 6 to 10. In total some 54 species were caught (Table 6). The largest number of species and total weight were obtained when fishing was carried out through the night (although it should be remembered that at this occasion fishing was carried out two to three times longer than during the day). The most abundant groups (total number) were sardins (Clupeidae), ponyfish (Leiognathidae) and catfish (Ariidae). Some species were obtained during the night only; such as catfish, snook (Centropomidae) and croakers (Scianidae). Triggerfish (Balistidae) were caught during daylight only. By weight the most important groups were catfish, sardins and herrings, therapons (Teraponidae), spadefish (Ephippidae) and rays (Rajidae).

The results of the sampling using theseine net are shown in Tables 11 to 15. Some 42 species were caught using the beach sein (Table 11). The most common groups were juveniles of mullets (Mugilidae), snooks, and silversides (Atherinidae). By weight the most important groups were tongue fish (Cynoglossidae) and flounder (Bothidae).

Despite the relatively limited effort, the study indicate that the Sipitang area is inhabited by a diverse fish fauna. Many of the approximately 240 species reported by CHUA and CHAW (1978) for West Sabah occured in the area. Several of the species obtained in the present study are of high commercial importance (jacks) and cavalla had a retail price of 6.50 to 7.30 Ringgit* $\mathrm{kg}^{-1}$ in Sipitang in 1983; the corresponding figure for mackerel was 5.60 to $7.20 \mathrm{Ringgit}^{-1}$ ). In addition it is also clear from the shallow water samplings .that these areas function as nursery and feeding areas for junveniles of commercially important species. Studies similar to the present one were carried out on the east coast of Peninsular Malaysia (TAN, 1984). Although the methods used were not exactly the same as those used in the present study, the results indicate that much larger number of specie ${ }^{\wedge}$ and larger quantities of young fish were obtained in the present study compared to what was found in the study at Peninsular Malaysia.

In conclusion, the present study has provided some basic information on the marine ecosystem of Brunei Bay. The investigation has shown a large variation in plankton diversity, biomass and productivity during the year. In November-December more species were present, the chlorphyll content was higher and the primary productivity higher than during April. This difference is likely to be at least partly related to the increased flush-out of nutrients from land during the rainy season. Furthermore the study has shown a rich fauna of fish in a relatively limited area.

\section{ACKNOWLEDGEMENT}

We thank Drs. S.O. Kullander, L. Edler and L. Hernroth for assistance in species determination offish, phytoplankton and zooplankton respectively. 


\section{REFERENCES}

CHUA TH1A-EENG, 1984. Coastal and riveries plankton of the east coast of Peninsular Malaysia. In: Coastal Resources of East Coast Peninsular Malaysia. Eds. : Chua Thia-Eng \& J.K. Charles. Penerbit Universiti Sains Malaysia, Pulau Pinang.

CHUA, T.E \& B.J. CHONG, 1973. Plankton distribution. IN: the Straits of Malacca, in Proceedings of the Special Symposium on Marine Science. Pacific Science Association, Hong Kong.

CHUA, T.E. \& L.H. CHAW , 1978, Fishes. In: Coastal Resources of West Sabah, Eds. : Chua ThiaEng \& J. Mathais. Universiti Sains Malaysia, Penang.

GARGAS, E (Ed.), 1975. A manual for phytoplankton primary production studies in the Baltic. Publs. Baltic Marine Biologists 2, 1-88 (Copies available from Water Quality Institute, 11 Agern Alle, DK-2970 Horsholm, Denmark.

LINDEN, 0., L LINDENSTROM \& B. CANNING, 1988. Tlie destruction of coral reefs in the inner part of Brunei Bay, Borneo, MS Submitted to Mar. Pollut. Bull

LA1NGREAU, JJP.; G STEPHENS \& L FELLOS, 1985. Remote sensing of rorest fires : Kalimantan and North Borneo in 1982-83. Ambio, XIV : 14-321.

MOHAMED, M, R STANFORTH an4 N JOHNSTON, 1984. Current and plankton studies in Brunei Bay 8-9 June 1984. Report by Universiti Kebangsaan Malaysia, Sabah Campus.

RYTHER, J.H, 1969. Relationship of photosynthesis to fish production in the sea. Science, 166 : 72-76.

TAN, E.S.P., 1984. The fish fauna of some beaches and estuaries along the coast of Peninsular Malaysia. in Coastal Resources of East Coast Peninsular Malaysia. Eds. : T.E. Chua \& J.K. Charles. Penerbit Universiti Malaysia, Pulau Pinang. 

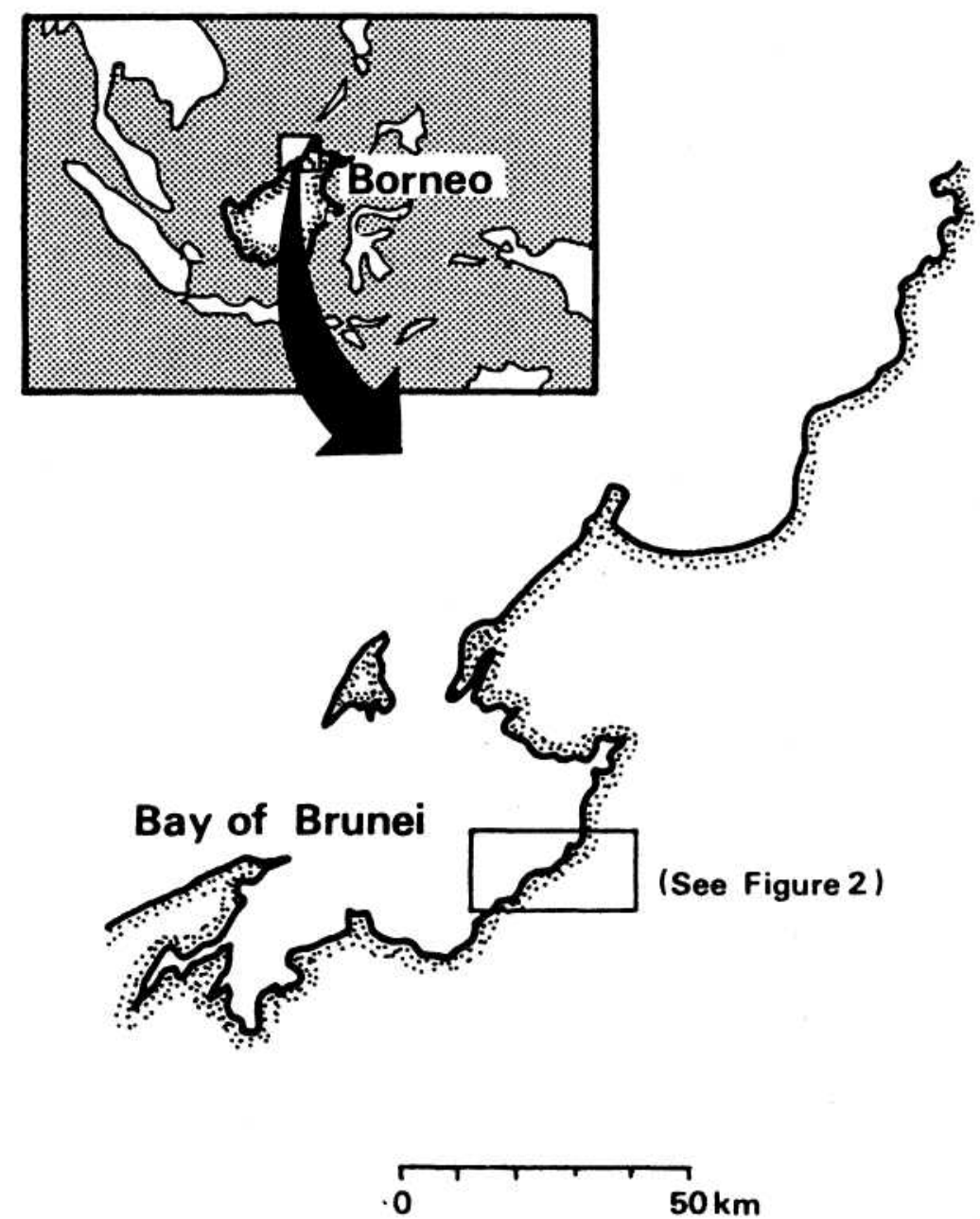

Figure 1. Location of Brunei Bay 


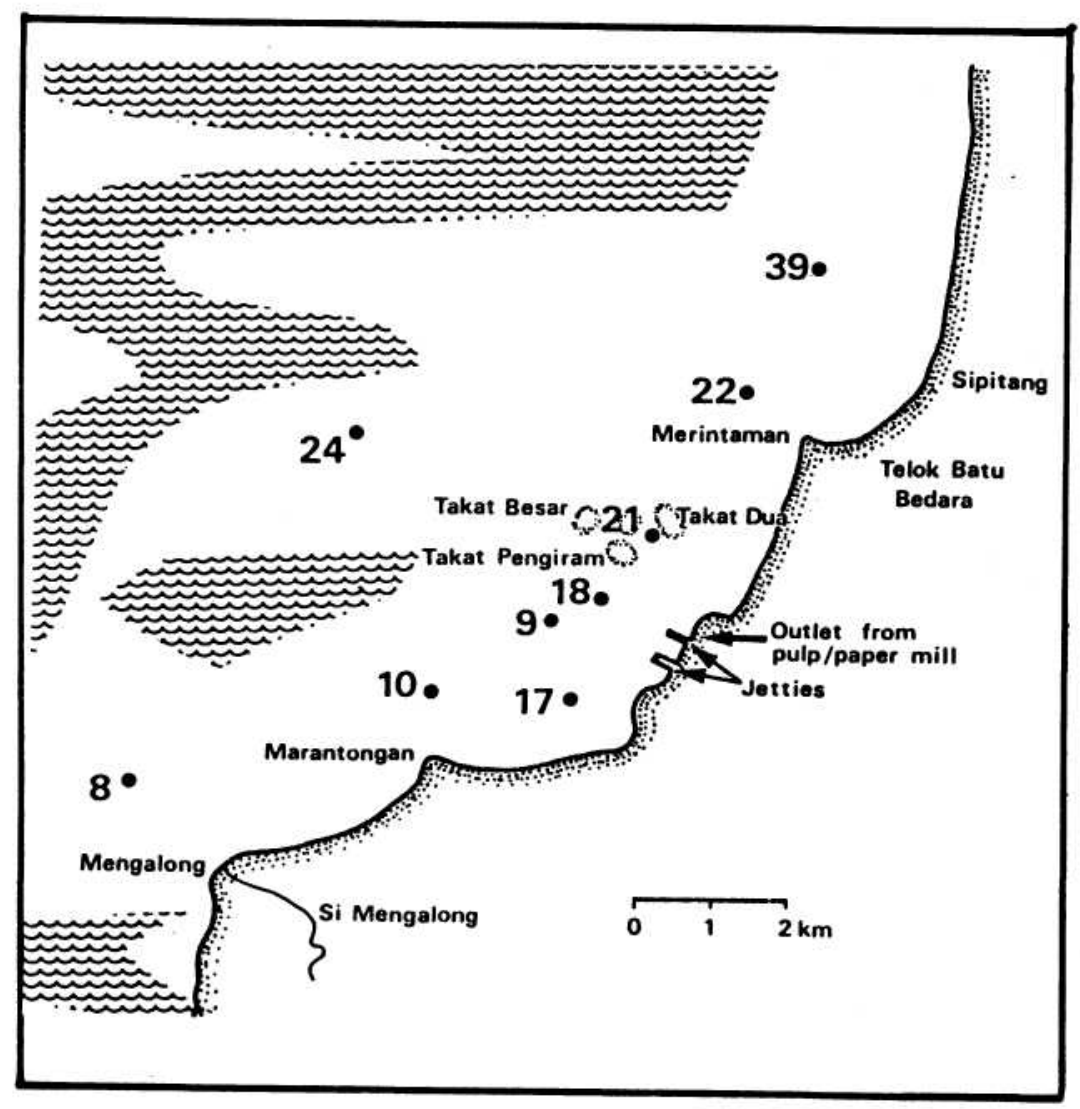

Figure 2. Location of station in The Brunei Bay 


\section{O. LINDEN; R GANNING \& L LINDSTROM}

Tabel 1. Phytoplanton caught in Brunei Bay in November-December 1984 and April 1985.

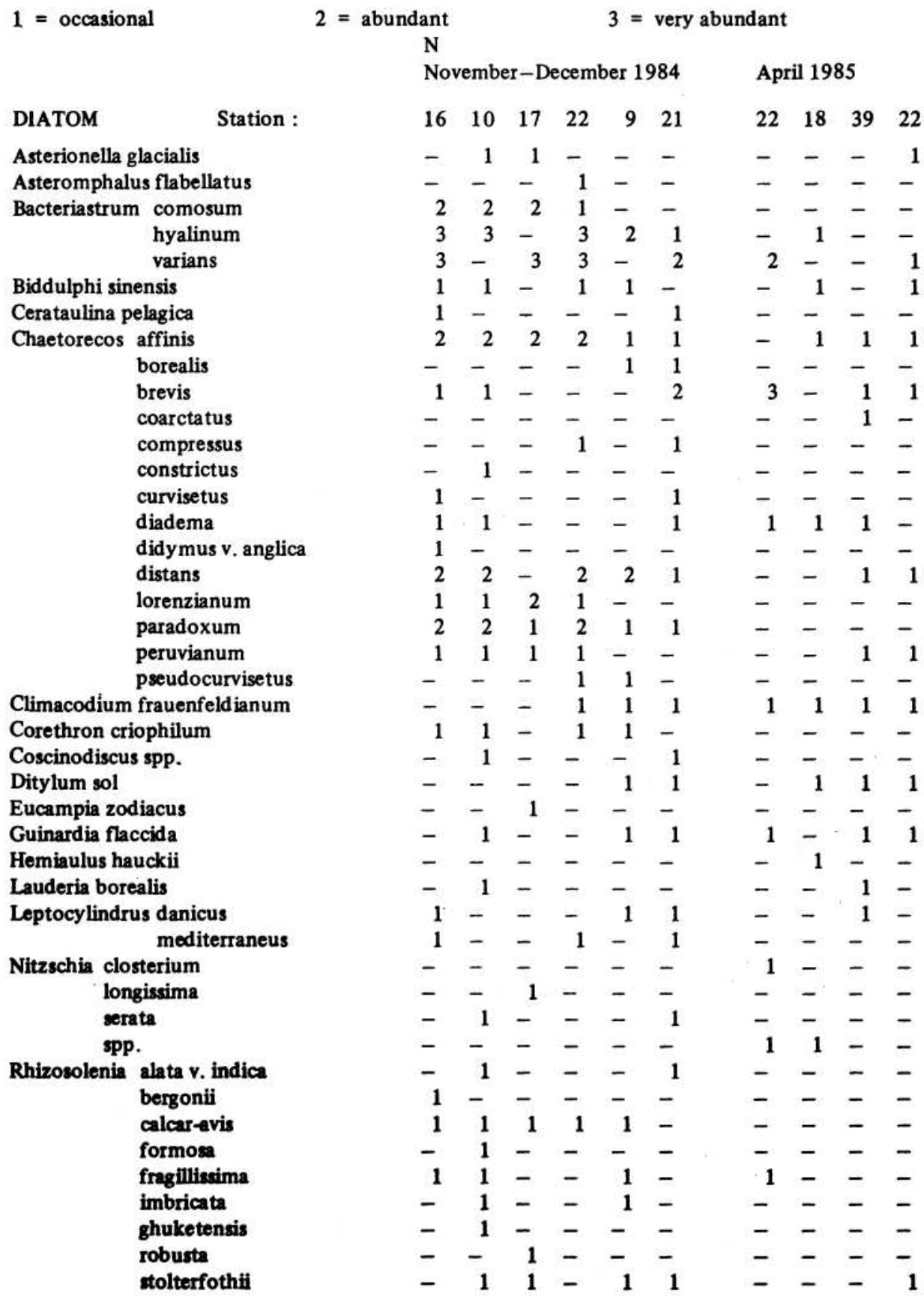


Studies on Plankton

Schroderella delicatula

Skeletonema costatum

Thalassionema nitzschioides

Thalassiosira spp.

Thalassiothrix longissima

$\begin{array}{rrrrrrrrrr}- & 1 & - & - & - & - & - & - & - & - \\ 1 & 1 & - & - & 1 & - & 1 & 1 & - & - \\ 1 & 1 & 1 & 1 & 1 & 1 & 1 & - & 1 & - \\ 1 & 1 & 1 & - & 1 & - & 1 & - & 1 & - \\ 1 & 1 & 1 & - & - & - & - & - & - & -\end{array}$

\section{DINOFLAGELLATES}

Ceratium breve

furca
fusus
macroceros
massiliense
trichoceros
tripos

Dinophysys caudata forma pedunculatum miles forma indica rotundata

Gonyaulax spp.

Gymnodinium spp.

Ornithocercus magnificus

Prorocentrum compressum

$$
\text { micans }
$$

rostratum

Protoperidinium claudicans

diabolus

divergens

globulus

leonis

oceanicum

sphaericum

spp.

Pyrophacus horologicum

\begin{tabular}{|c|c|c|c|c|c|c|c|c|c|}
\hline- & - & - & - & - & - & 1 & - & 1 & 1 \\
\hline- & 1 & - & 1 & 1 & 1 & 1 & 1 & 1 & 1 \\
\hline 1 & 1 & - & - & 1 & 1 & 1 & 1 & 1 & 1 \\
\hline- & - & - & - & - & - & 1 & - & 1 & - \\
\hline 1 & 1 & 1 & - & - & 1 & - & 1 & - & 1 \\
\hline 1 & 1 & - & 1 & - & 1 & 1 & - & 1 & 1 \\
\hline - & 1 & 1 & 1 & - & - & - & - & 1 & - \\
\hline 1 & 1 & - & 1 & 1 & 1 & - & 1 & 1 & 1 \\
\hline 1 & - & - & - & 1 & 1 & - & 1 & 1 & 1 \\
\hline- & - & - & - & - & 1 & - & - & 1 & - \\
\hline 1 & - & - & - & 1 & 1 & 1 & 1 & 1 & 1 \\
\hline- & - & - & - & - & 1 & - & - & 1 & - \\
\hline 1 & 1 & 1 & - & 1 & 1 & - & 1 & 1 & 1 \\
\hline- & - & - & - & 1 & - & - & - & - & - \\
\hline- & - & - & 1 & 1 & - & - & - & 1 & - \\
\hline- & - & - & - & - & 1 & 1 & 1 & 1 & - \\
\hline 1 & - & - & - & 1 & 1 & - & 1 & 1 & - \\
\hline- & - & - & - & - & 1 & 1 & 1 & - & - \\
\hline- & - & - & - & - & 1 & 1 & - & - & - \\
\hline 1 & 1 & 1 & - & 1 & - & - & - & - & - \\
\hline 1 & - & - & - & - & - & - & - & - & - \\
\hline- & - & - & 1 & - & 1 & - & - & - & - \\
\hline 1 & 1 & - & 1 & 1 & - & - & - & - & - \\
\hline 1 & - & 1 & - & - & 1 & 1 & 1 & 1 & 1 \\
\hline & - & - & - & - & - & 1 & 1 & - & \\
\hline
\end{tabular}

\section{SILICOFLAGELLATES}

Dictyocha fibula

\section{CYANOPHYTA}

Oscillatoria spp. 
O. LINDEN ;B. GANNING \& L LINDSTROM

Table 2. Determination of chlorophyll a in water samples from Brunei Bay.

\begin{tabular}{|c|c|c|c|}
\hline Date & Station & $\begin{array}{l}\text { Depth } \\
\text { (m) }\end{array}$ & $\begin{array}{c}\text { Chlorophyll A } \\
\text { (microgram) }\end{array}$ \\
\hline $22 / 11(1984)$ & 18 & 0.5 & 0.76 \\
\hline $22 / 11$ & 18 & 5 & 0.53 \\
\hline $22 / 11$ & 18 & 15 & 0.66 \\
\hline $26 / 11$ & 21 & 0.5 & 0.37 \\
\hline $26 / 11$ & 21 & 15. & 0.85 \\
\hline $26 / 11$ & 22 & 0.5 & 0.95 \\
\hline $26 / 11$ & 22 & 15 & 0.60 \\
\hline $30 / 11$ & 39 & 0.5 & 0.89 \\
\hline $30 / 11$ & 39 & 15 & 0.16 \\
\hline $7 / 12$ & 18 & 0.5 & 0.97 \\
\hline $7 / 12$ & 18 & 15 & 0.68 \\
\hline $19 / 4(1985)$ & 18 & 0.5 & 0.21 \\
\hline $19 / 4$ & 18 & 17.5 & 0.26 \\
\hline $19 / 4$ & 24 & 0.5 & 0.33 \\
\hline $19 / 4$ & 24 & 10 & 0.39 \\
\hline $19 / 4$ & 24 & 20 & 0.21 \\
\hline $20 / 4$ & 39 & 0.5 & 0.25 \\
\hline $20 / 4$ & 39 & 5 & 0.26 \\
\hline $20 / 4$ & 39 & 16 & 0.25 \\
\hline $21 / 4$ & 22 & 0.5 & 0.16 \\
\hline $21 / 4$ & 22 & 16 & 0.31 \\
\hline $21 / 4$ & 18 & 0.5 & 0.12 \\
\hline $21 / 4$ & 18 & 17 & 0.43 \\
\hline
\end{tabular}




\section{Studies on Plankton}

Table 3. Primary production in Brunei Bay 1984 and 1985

\begin{tabular}{|c|c|c|c|c|}
\hline \multicolumn{2}{|l|}{ Date } & \multicolumn{2}{|c|}{ Production : $\mathrm{mg} \mathrm{C} \mathrm{m}^{-2} \mathrm{hr}^{-1}$} & \multirow{2}{*}{$\begin{array}{c}\text { Station } \\
18\end{array}$} \\
\hline 1984 & Nov 22 & & 42,36 & \\
\hline & Dec 7 & & 50,69 & 18 \\
\hline & Nov 26 & & 53,31 & 21 \\
\hline & Nov 26 & & 50,25 & 22 \\
\hline & Nov 30 & & 36,47 & 39 \\
\hline & & mean : & 47,02 & \\
\hline \multirow[t]{6}{*}{1985} & April 19 & & 15,58 & 18 \\
\hline & April 21 & & 13,21 & 18 \\
\hline & April 21 & & 19,39 & 22 \\
\hline & April 18 & & 12,40 & 22 \\
\hline & April 19 & & 17,60 & 24 \\
\hline & & mean : & 15,64 & \\
\hline
\end{tabular}


Table 4. Zooplankton caught in Brunei Bay in November-December 1984

$\mathbf{x}=$ single specimen $; \quad \mathbf{x x}=$ occasional $; \quad \mathbf{x x x}=$ abundant $; \quad \mathbf{x x x}=$ very abundant

Station :

$\begin{array}{lllllll}8 & 9 & 10 & 17 & 18 & 21 & 22\end{array}$

PROTOZOA

Tintinnids

$\mathbf{x}$

$\mathbf{x}$

\section{METAZOA}

Hydrozoa

Hydroidea

Siphonophora

Chaetognatha

Mollusca

Bivalvia

Gastropoda

Echinodermata

Tunicata

Appendiculariae

Doliolida

Polychaeta

Nemertini

Pilidium larvae

$\begin{array}{lllllll} & & \mathbf{x} & \mathbf{x} & \mathbf{x} & \mathbf{x} & \\ \mathbf{x} & \mathbf{x} & \mathbf{x} & \mathbf{x} & & & \\ \mathbf{x x} & \mathbf{x x} & \mathbf{x x} & \mathbf{x x} & \mathbf{x x} & \mathbf{x x} & \mathbf{x x}\end{array}$

Bryozoa

Cyphonautes larvae

Brachiopoda

Crustacea

Cirripedia

Ostracoda

Cladocera

Copedoda

Calanoids

Cyclopoids

Harpacticoids

$\begin{array}{lllllll} & & \mathbf{x x} & \mathbf{x x} & \mathbf{x} & \mathbf{x} & \mathbf{x} \\ \mathbf{x} & \mathbf{x} & \mathbf{x} & \mathbf{x} & \mathbf{x} & \mathbf{x} & \mathbf{x} \\ \mathbf{x} & & & \mathbf{x x} & \mathbf{x} & & \mathbf{x x}\end{array}$

$\begin{array}{llllll}\mathbf{x x} & \mathbf{x x} & \mathbf{x x} & \mathrm{xx} & \mathbf{x x} & \mathbf{x x}\end{array}$

$\begin{array}{llll}x & x x & x x\end{array}$

$\begin{array}{llllllll}\mathbf{X} & \mathbf{x} & \mathbf{x} & \mathbf{x} & \mathbf{x x} & \mathbf{x} & \mathbf{x x}\end{array}$

Decapoda

Prawn larvae

Crab larvae

$\begin{array}{lllllll} & & \mathbf{x} & & & & \mathbf{x} \\ & & & & & & \\ \mathbf{x x} & & \mathbf{x} & \mathbf{x x} & & \mathbf{x} & \mathbf{x x} \\ \mathbf{x} & \mathbf{x x} & \mathbf{x x} & \mathbf{x x} & \mathbf{x} & \mathbf{x x x} & \mathbf{x x} \\ \mathbf{x} & \mathbf{x x} & \mathbf{x x} & \mathbf{x x} & \mathbf{x x} & \mathbf{x x} & \mathbf{x x} \\ & & & & & & \\ \mathbf{x x x} & \mathbf{x x} & \mathbf{x x x} & \mathbf{x x x} & \mathbf{x x x} & \mathbf{x x x} & \mathbf{x x x} \\ \mathbf{x x x} & \mathbf{x x} & \mathbf{x x x} & \mathbf{x x x} & \mathbf{x x x} & \mathbf{x x} & \mathbf{x x x} \\ \mathbf{x x} & \mathbf{x} & \mathbf{x x} & \mathbf{x x x} & \mathbf{x x} & \mathbf{x x} & \mathbf{x x} \\ & & & & & & \\ \mathbf{x} & \mathbf{x x} & \mathbf{x x} & \mathbf{x x} & \mathbf{x} & \mathbf{x x} & \mathbf{x x} \\ \mathbf{x} & & \mathbf{x x} & \mathbf{x} & \mathbf{x} & \mathbf{x} & \mathbf{x}\end{array}$




\section{Studies on Plankton}

Table 5. Zooplankton caught in Brunei Bay in April 1985.

$\mathrm{x}=$ single specimen; $\quad \mathrm{xx}=$ occasional $; \quad \mathrm{xxx}=$ abundant $; \quad \mathrm{xxxx}=$ very abundant

\section{Station :}

$\begin{array}{llll}18 & 22 & 22 & 39\end{array}$

$18 / 4 \quad 21 / 4$

\section{PROTOZOA}

Tintinnids

METAZOA

Hydrozoa

Hydroidea

Siphonophora

Chaetognatha

Mollusca

Bivalvia

Gastropoda

Echinodermata

Tunicata

Appendiculariae

Doliolida

Polychaeta

Nemertini

Pillidium larvae

Bryozoa

Cyphonautes larvae

Brachiopoda

Crustacea

Cirripedia

Ostracoda

Cladocera

Copepoda

Calanoids

Cyclopoids

Harpacticoids

\section{Decapoda}

Prawn larvae

Crab larvae $\mathbf{x}$

$\begin{array}{llll}\mathbf{x} & \mathbf{x x} & & \\ \mathbf{x x x} & \mathbf{x x x} & \mathbf{x x x} & \mathbf{x x} \\ & & & \\ \mathbf{x} & \mathbf{x} & \mathbf{x x} & \\ & \mathbf{x} & \mathbf{x} & \\ & \mathbf{x} & \mathbf{x x} & \\ & & & \\ \mathbf{x x x} & \mathbf{x x x} & \mathbf{x x x} & \mathbf{x x} \\ \mathbf{x} & & \mathbf{x x} & \\ \mathbf{x} & \mathbf{x x} & \mathbf{x x} & \mathbf{x}\end{array}$

$\mathbf{x}$

$\mathbf{x}$

$\begin{array}{llll} & \mathbf{x} & & \mathbf{x x} \\ \mathbf{x x} & \mathbf{x} & \mathbf{x x} & \mathbf{x x} \\ \mathbf{x} & & & \\ & & & \\ \mathbf{x x x} & \mathbf{x x x} & \mathbf{x x x} & \mathbf{x x} \\ \mathbf{x x x} & \mathbf{x x \mathbf { x }} & \mathbf{x x \mathbf { x }} & \mathbf{x x} \\ \mathbf{x x x} & \mathbf{x x} & \mathbf{x x} & \mathbf{x x}\end{array}$

$\begin{array}{lll}\mathbf{x} & \mathbf{x}\end{array}$ 


\section{O. LINDEN; B. CANNING \& L LiNDSTROM}

Table 6. Ust of fish species caught using survey net in the coastal area of Sipitang, November-December 1984.

Ariidae

Arius doriae

A. sagor

Balistidae

BaJistes stellatus

Bothidae

Pseudorhombus javanicus .

P. malayanus

P. oilgodon

Carangidae

Alectis ciliaris

Caranx ignobilis

Caranx

Carangoides praeuctus

C uii

Carangoides

Scomberomorus tol

Selaroides leptolepis

Centropomidae

Ambassis kopsii A.

urotaenia

Clupeidae

Anotontostoma chacunda

Sardinella fimbriata $S$.

melanura Sardinella

Cynoglossidae

Cynoglossus

Dasyatidae

Himantura. 1

Himantura 2

Ephippidae

Drepane punctata
Eugraulidae

Eugraulis kammalensis

E. mystax

Stolephorus heterolobus 
Table 6. (continued)

Gerreidae

Genes abbreviatus

G. filamentosus

G. kapas

G. punctatus

Leiognathidae

Gazza minuta

Leiognathus bindus

L. elongates

L. leuciscus

L. lineolatus $L$ ruconius

L. splendent

L. sp. (cf. daura)

Lutjanidae

Chelon dussumieri

Mullidae

Upeneus moluccensis $\mathbf{U}$.

sulphureus

Nemipteridae

Nemipterus faponicus

N. peronil

Rajidae

Raja sp.

Sciacnidae

Pseudoscianidae doldado

Scorpaenidae

Parascorpaena picta

Serranidae

Epinephelus merra

E. sexfasiatus

Soleidae

Pardachims pavoninus

Teraponidae

Terapon puta

Trichiuridae

Trichiurus lepturus 


\section{O. LINDEN; B. CANNING \& L LINDSTROM}

Table 7. Fish species, number of individuals (A) and total weight in grams (B) for each species, caught by survey nets at 2 m depth 400 m NW of Tg Merintaman. Fishing was carried out during 13 hrs in the night, November 1984.

\section{(A) (B)}

Ariidae

Arius doriae

A sagor

$25 \quad 2252$

Bothidae

Pseudorhombeus oilgodon

$1 \quad 150$

Carangidae

Carangoides praeustus

C uii

Scomberomorus tol

$\begin{array}{rr}3 & 160 \\ 2 & 100 \\ 4 & 91\end{array}$

Centropomidae

Ambassis (Chanda) kopsii

A. urotaenia

$2 \quad 12$

$3 \quad 30$

Clupeidae

Anatontostoma (Dorosoma) chacunda $\quad 24 \quad 312$

Sardinella fimbriata $\quad 185 \quad 2220$

Sardinella

3.168

Cynoglossidae

Cynoglossus sp.

$2 \quad 68$

Centropomidae

Himanturasp. 1

$3 \quad 330$

Himantura

1102

Eugraulidae

Eugraulis (Thryssa) kammalensis

E. mystax

$10 \quad 150$

Stolephorus heterolobus

$5 \quad 50$

Ephippidae

Drepane punctata

$5 \quad 150$

Gerridae

$\begin{array}{lll}\text { Gerres abbreciatus } & 10 & 445\end{array}$

Leiognathidae

Gazzaminuta

49500

Leiognathus elongatus

$13 \quad 65$


Table 7. (continued)

Mugilidae

Chelon dussumieri

Sciaenida

Pseudosciaena soldado

Scorpaenidae

Parascorpaena picta

1

Serranidae

Epinephelus merra

Soleidae

Pardachirus pavoninus

Trichiuridae

Trichiunus leptunus

$3 \quad 600$

Table 8. Fish species, number of individuals (A) and total weight in grams (B) for each species, caught by survey nets during 4 hrs at $17.5 \mathrm{~m}$ depth $400 \mathrm{~m} \mathrm{E}$ of jetties. November 1984. Fishing was carried out during day time.

Family and species

(A)

(B)

Carangidae

Carangoides uii

Clupeidae

Sardinella fimbriata

450

S. melanura

18

Dasyatidae

Himantura sp. 3

1 . 170

Drepanidae

Drepane punctata

1160

Eugraulidae

Stolephorus heterolobus

$\begin{array}{ll}3 & 8\end{array}$

Gerridae

Gerres filamentosus

Leiognathidae

Leiognathus bindus 
O. LINDEN; R GANNING \& L LiNDSTROM
L. elngoatus
L. leuciscus
L. lineolatus
L. nuconius
L. splendens

$\begin{array}{rr}5 & 52 \\ 1 & 15 \\ 2 & 11 \\ 20 & 126 \\ 4 & 10\end{array}$

Mullidae

Upeneus sulphureus

Nemipteridae

Neimpterus japonicus

Serranidae

Epinephelus sexfasciatus

Table 9. Fish species, number of individuals (A) and total weight in grams (B) for each species, caught by survey nets at $15 \mathrm{~m}$ depth at Takat Dua Darat, $2 \mathrm{~km}$ SE of Tg. Merintaman. Fishing was carried out during 3.5 hrs at day time in November 1984.

(A)

Balistidae

Aleutera monoceros

1400

Carangidae

Alectis ciliaris

Ephippidae

Drepane punctata

Lutjanidae

Lutjanus sanguineus

Nemipteridae .

Nemipterus japonicus

N. peronii

Rajidae

Raja sp.

2700

Teraponidae

Terapon puta

$700 \quad 1050$ 
Table 10. Fish species, number of individuals (A) and total weight (B) for each species caught by survey nets during 2.5 hrs at $10 \mathrm{~m}$ depth $500 \mathrm{~m} \mathrm{SE}$ of $\mathrm{Tg}$ Merinta man. November 1984. Fishing was carried otu during day time.

Family and species

Balistidae

Balistes stellatus

(A)

(B)

Bothidae

Pseudorhombus javanicus

P. malayanus

Carangidae

Caranx ignobilis

Caranx

Carangoides

Selaroides leptolepis

Clupeidae

Sardinella fimbriata

Sardinella

Ephippidae

Drepane punctata

Gerridae

Gerres abbreviatus

G. filamentosus

G. kapas

G. punctatus

Leiognathidae

Leiognathus splendens

L. sp. leuciscus)

$L$ sp. (cf. doura)

Lutjanidae

Lutjanus sp.

Mullidae

Upeneus moluccensis
2

1190

1190

1104

$1 \quad 100$

$3 \quad 61$

113

110

$2 \quad 544$

143

$2 \quad 118$

$4 \quad 95$

252

$3 \quad 11$

122

16

156

120 


\section{O. LINDEN; R GANNING \& L LiNDSTROM}

Table 11. List of fish species caught using beach sein net in the coastal area of Sipitang. November-December 1984.

Apogonidae

Apogon cf. fasciatus

Gen. et. sp. indet.

Ariidae

Arius sp.

Atherinidae

Atherina sp. 1

Atherina

Atherina

Belonidae

Tylosurus crocodilus

T. strongylurus

Bothidae

Pseudorhombus javanicus

Callionymidae

Repomucenus sagitta

Carangidae

Carangoides praeustus

Gen. et. sp. indet.

Centropomidae

Ambassis kopsii

A. urotaenia

Cynoglossidae

Arelia bilineata

Cynoglossus bilineatus

Cynoglossus

Paraplagusia bilineata

P. blochii

Eugraulidae

Stolephorus heterolobus

$S$. indicus

S. tri

Gerreidae

Gerres macracanthus

Gerres 
Studies on Plankton

Table 11. continued

Gobiidae

Acentrogobius bontil

Acentrogobius

Favonigobius reichei

Hemirhamphidae

Hyporhampus gaimardi

Zenarchopterus

Leiognathidae

Leiognathus equulus $L$.

fasciatus Leiognathus

Gazza minuta

Mugilidae

Chelon vaigiensis

Mugil sp.

Nemipteridae

Nemipterus peronil

Platycephalidae

Platycephalus bataviensis

Sillaginidae

Sillago japonica

S. maculata

Teraponidae

Terapon jarbua

Tetraodontidae

Sphoeroides honckenii

Tetraodon patoca

Table 12. Fish species, number of individuals (A) and the total weight in grams (B), caught using a sein net in the shallow water outside the mangroves $300 \mathrm{~m} \mathrm{~W}$ of the mouth of Si Marantongan. Four shootings of the net was conducted at day time, November 1984.

(A)

(B)

Ariidae

Arius sp. (juv) 


\section{LINDEN;B. GANN1NG \& L LINDSTROM}

Atherinidae

Atherina sp. 3

Centropomidae

Ambassis kopsii

Gobiidae

Favonigobius reichei

Hemirhamphidae

Zenarchoptenus sp.

Mugilidae

Chelon vaigiensis

Nemipteridae

Nemipterus peronii

Tetraodontidae

Tetraodon patoca

Leiognathidae

Leiognathus fasciatus

Table 13. Fish species, number of individuals (A) and the total weight in grams (B), caught using a sein net on the beach $1.4 \mathrm{~km} \mathrm{NW}$ of the jetties. Five shootings of the net was conducted at day time, November 1984.
(A)

Centropomidae

Ambassis urotaenia (juv)

Cynoglossidae

Paraplagusia bilineata

Atherinidae

Atherina sp 1

Eugraulidae

Stolephorus indicus

\section{Gerreidae}

Gerres sp. (juv)

Hemirhamphidae Hyporhampus gaimardi

\section{Leiognathidae}


Mugilidae

Chelon vaigiensis (juv)

60

75

Table 14. Fish species, number of individuals (A) and the total weight in grams (B), caught using a sein net on the beach $1 \mathrm{~km} \mathrm{~S}$ of $\mathrm{Tg}$ Merintaman. Seven shotings of the net was conducted at day time, November 1984.

(A)

Belonidae

Tylosurus strongylurus

Bothidae

Pseudorhombus javanicus

Centropomidae

Ambassis urotaenia

Cynoglossidae

\section{Arelia bilineata}

Cynoglossus bilineatus

Cynoglossus

Paraplagusia bilineata

P. blochii

Eugraulidae

Stolephorus tri

Gerreidae

Gerres sp. (juv)

Leiognathidae

Leiognathus equulus

Gazza minuta

Mugilidae

Chelon vaigiensis

Sillaginidae

Sillago japonica

Teraponidae

Terapon jarbua

Tetraodontidae 


\section{O. LINDEN; B. GANN1NG \& L LINDSTROM}

Table 15. Fish species, number of individuals (A) and the total weight in grams (B), caught using a sein net in the shallow water outside the mangroves in Telok Batu Bedara in the mouth of Si Merintaman. Seven shootings of the net was conducted at day time, November 1984.

\section{( A ) (B)}

Apogonidae

Apogon cf. fasciatus

Gen. et. sp. indet.

1

1

5

therinidae

Atherina sp. 1

Atherina

Belonidae

Tylosurus crocodilus

T. strongylunus

\section{Carangidae}

Carangoides praeustus

Gen. et. sp. indet. (juv)

Centropomidae

Ambassis kopsii

Cynolossidae

\section{Arella bilineata}

Eugraulidae

Stolephorus heterolobus

Gerreidae

Gerres macracanthus

Gobiidae

Acentrogobius bontii

Acentrogobius

Favonigobius reichei

$\begin{array}{ll}3 & 5\end{array}$

$1 \quad 1$

$4 \quad 4$

\section{Leiognathidae}

Leiognathus sp. (juv)

Mugilidae

Chelon vaigiensis

Mugil sp. (juv) 
Studies on Plankton

Platycephalidae

Platycephalus bataviensis

Sillaginidae

Sillago maculata

Teraponidae

Terapon jarbua
1

10

3

26

1 